\title{
Gonadal Steroid Attenuation of Developing Hamster Facial Motoneuron Loss by Axotomy: Equal Efficacy of Testosterone, Dihydrotestosterone, and 17- $\beta$ Estradiol
}

\author{
Christopher B. Huppenbauer, ${ }^{1,2}$ Lisa Tanzer, ${ }^{1}$ Lydia L. DonCarlos, ${ }^{1}$ and Kathryn J. Jones ${ }^{1,2}$ \\ ${ }^{1}$ Department of Cell Biology, Neurobiology, and Anatomy, Loyola University Chicago, Stritch School of Medicine, Maywood, Illinois 60153, and 2Research \\ and Development Service, Hines Veterans Affairs Hospital, Hines, Illinois 60141
}

In the hamster facial nerve injury paradigm, we have established that androgens enhance both functional recovery from facial nerve paralysis and the rate of regeneration in the adult, through intrinsic effects on the nerve cell body response to injury and via an androgen receptor (AR)-mediated mechanism. Whether these therapeutic effects of gonadal steroids encompass neuroprotection from axotomyinduced cell death is the focus of the present study. Virtually $100 \%$ of adult hamster facial motoneurons (FMNs) survive axotomy at the stylomastoid foramen (SMF), whereas, before postnatal day 15 (P15), developing FMNs undergo substantial axotomy-induced cell death. The first part of the present study focuses on determining when ARs are first expressed in developing hamster FMNs. Using AR immunocytochemistry, it was found that males express ARs by P2 and females by P4, which is the earliest demonstration of AR expression in mammalian motoneurons reported thus far in the literature. The second half examines the neuroprotective effects of testosterone propionate, 17- $\beta$ estradiol, and dihydrotestosterone on FMNs of P7 hamsters after facial nerve transection at the SMF. The results demonstrate that androgens and estrogens are equally able to rescue $\sim 20 \%$ of FMNs from axotomy-induced cell death, with the effects permanent. This study is the first to investigate the effects of both androgens and estrogens on axotomy-induced cell death in one system and, with our previously published work, to validate the hamster FMN injury paradigm as a model of choice in the investigation of both neurotherapeutic and neuroprotective actions of gonadal steroids.

Key words: androgen receptor; testosterone; estrogen; dihydrotestosterone; motoneuron; development; peripheral nerve injury

\section{Introduction}

Work from our laboratory and others has provided a growing body of literature documenting that gonadal steroids positively impact the reparative response of injured neurons, thus supporting the emerging role of gonadal steroids as potent neurotherapeutic agents (Yu, 1982; Jones, 1988, 1993a,b; Azcoitia et al., 1999a,b; Garcia-Segura et al., 2001; Jones et al., 2001; Behl, 2002a; MacLusky et al., 2003; Fargo and Sengelaub, 2004; Tanzer and Jones, 2004). Using the adult hamster facial motoneuron (FMN) as a model, we have established that administration of supraphysiological doses of exogenous testosterone propionate (TP), coincident with facial nerve injury at the stylomastoid foramen, accelerates facial nerve regeneration and functional recovery in the adult hamster (Kujawa et al., 1989, 1991; Kujawa and Jones, 1990). Recently, numerous studies have been published indicat-

\footnotetext{
Received Dec. 27, 2004; revised March 5, 2005; accepted March 9, 2005.

This work was supported by National Institutes of Health Grant NS-28238 (K.J.J.), United States Public Health Service Grants MH62588 and MH48794 (L.L.D.), and National Science Foundation Grant IBN-9604487 (L.L.D.). We thank Diane Stancik and Betty Lorenz for their technical assistance with the androgen receptor immunocytochemistry experiments. We also thank Dr. Stephen Fish of Marshall University for his input on hamster breeding.

Correspondence should be addressed to Dr. Kathryn J. Jones, Department of Cell Biology, Neurobiology, and Anatomy, Loyola University Chicago, Stritch School of Medicine, Fifth Floor, 2160 South First Avenue, Maywood, IL 60153. E-mail: kjones1@lumc.edu.

DOI:10.1523/JNEUROSCI.5279-04.2005

Copyright $\odot 2005$ Society for Neuroscience $\quad$ 0270-6474/05/254004-10\$15.00/0
}

ing that estrogen (E) can act as a neuroprotective agent to alter neuronal survival levels in response to injury (Garcia-Segura et al., 2001; Wise, 2002) through a broad spectrum of mechanisms that may or may not depend on estrogen receptor (ER) expression in target neurons. In view of these data, and given that TP can be metabolized to E, we examined the ability of E to alter the regenerative properties of injured FMNs in a recent study (Tanzer and Jones, 1997) and found that $17-\beta$ estradiol $\left(E_{2}\right)$ is as effective as either TP or dihydrotestosterone (DHT) in enhancing peripheral nerve regeneration in this model. Although androgens appear to augment the regenerative properties of injured FMNs by an androgen receptor (AR)-dependent mechanism (Kujawa et al., 1995), how $\mathrm{E}$ acts in the same system is unclear, because the presence of ERs has yet to be established in motoneurons.

In the hamster FMN injury paradigm, virtually all adult neurons survive a facial nerve transection at the stylomastoid foramen, whereas there is a significant degree of axotomy-induced loss during early postnatal development (LaVelle and LaVelle, 1984). Whether androgens can rescue mammalian motoneurons from cell death after injury has not been established. Yu and Cao (1992) found that axotomized postnatal day 10 (P10) rat FMNs could not be rescued by androgens but also noted the lack of AR expression in rat FMNs at that developmental time point. Therefore, the purpose of the first part of the current study is to determine at what age developing hamster FMNs begin to express ARs. 
In the second half of the current study, we test the ability of both androgens and estrogens to rescue developing FMNs from axotomy-induced cell death at a time point when ARs are found to be present in FMN cell bodies. The results indicate that developing hamster FMNs express ARs earlier in development than previously reported in mammalian motoneurons and that, with ARs present in the injured cell bodies, both androgens and estrogens are neuroprotective. Furthermore, this study validates the hamster FMN as an ideal injury paradigm in which to elucidate cellular pathways associated with neuronal survival versus regeneration and the underlying distinctions between androgenic and estrogenic neurotherapeutic actions.

\section{Materials and Methods}

Animals. Male and female golden Syrian hamsters (Mesocricetus auratus), ranging in age from P0 to P10, were used for all studies. Pregnant dams were housed on a $12 \mathrm{~h} \mathrm{light/dark} \mathrm{cycle} \mathrm{and} \mathrm{checked} \mathrm{for} \mathrm{signs} \mathrm{of} \mathrm{parturi-}$ tion at the beginning, middle, and end of the daily light cycle. The day of birth was designated P0. Four hours after the completion of parturition, the litters were culled, so that each litter consisted of two males and two females. All surgical procedures and the killing of the animals were performed under National Institutes of Health Guidelines on the Care and Use of Animals for Research Purposes, and all protocols involving animals were approved by the appropriate institutional animal care and use committees.

Androgen receptor immunocytochemistry studies. Gonadally intact P0, P2, P4, P6, P8, and P10 male and female hamsters were removed from the nest cage, their body weights were recorded, and gender was determined by measuring the ano-genital distance with a digital caliper. Pups were injected subcutaneously with TP in sesame seed oil (P0, $10 \mu \mathrm{g} / 0.1 \mathrm{ml} ; \mathrm{P} 2$ and P4, $15 \mu \mathrm{g} / 0.1 \mathrm{ml}$; $\mathrm{P} 6$ and P8, $30 \mu \mathrm{g} / 0.1 \mathrm{ml}$; $10,40 \mu \mathrm{g} / 0.01 \mathrm{ml}$ ) in the dorsum of the back, 30-90 min before perfusion-fixation to ensure nuclear localization of the AR (Zhou et al., 1994; Nunez et al., 2003). P0-P7 pups were anesthetized deeply by cryoanesthesia, and pups older than P7 were anesthetized with methyoxyflurane (Medical Developments Australia, Springvale, Australia) and then killed by transcardiac perfusionfixation with a saline rinse and 4\% paraformaldehyde in $25 \mathrm{~mm}$ PBS. Brains were removed immediately and postfixed for $24 \mathrm{~h}$ in $4 \%$ paraformaldehyde, equilibrated for $24 \mathrm{~h}$ in $20 \%$ sucrose in $25 \mathrm{~mm}$ PBS, and transferred to $30 \%$ sucrose at $4^{\circ} \mathrm{C}$ until sectioning. Postmortem dissection of the gonads was done to verify sex. Brains were blocked to include the facial nuclei and rapidly frozen; next, $40 \mu \mathrm{m}$ sections were collected into a cryoprotected sucrose solution for storage at $-20^{\circ} \mathrm{C}$ until tissue processing. There was an $n=4$ per time point and sex, for a total of 48 animals.

Free-floating brainstem sections containing facial nuclei were rinsed five times for $15 \mathrm{~min}$ in $25 \mathrm{~mm}$ PBS and then incubated in PBS containing $0.02 \%$ Triton X-100 (TX) and 4\% normal goat serum (NGS) for $1 \mathrm{~h}$ at room temperature (Rt), followed by five $15 \mathrm{~min}$ PBS rinses. Subsequently, the sections were incubated in primary polyclonal rabbit anti-AR antisera, PG-21 $(1.5 \mu \mathrm{g} / \mathrm{ml}$ final concentration; corresponding to the first 21 aa of the human and rat AR; gift from Dr. Gail Prins, University of Illinois at Chicago, Chicago, IL) (Prins et al., 1991; Prins and Birch, 1993), for $48 \mathrm{~h}$ at $4^{\circ} \mathrm{C}$ in PBS containing $0.02 \%$ TX and $4 \%$ NGS, followed by five $15 \mathrm{~min}$ rinses in PBS. Sections were then incubated in biotinylated goat anti-rabbit IgG (1:250; Vector Laboratories, Burlingame, CA) for $24 \mathrm{~h}$ at $4^{\circ} \mathrm{C}$, followed by five $15 \mathrm{~min}$ PBS rinses. Sections were then incubated in avidin-biotin horseradish peroxidase complex (1:100; Vectastain ABC Elite; Vector Laboratories) for $1 \mathrm{~h}$ at Rt, followed by three $10 \mathrm{~min}$ PBS rinses and two $10 \mathrm{~min} 0.1 \mathrm{M}$ Tris buffer rinses. For the chromagen reaction, sections were incubated in $25 \% 3,3^{\prime}$ diaminobenzadine (DAB; Sigma, St. Louis, MO) in 2.6\% nickel-ammonium sulfate-Tris buffer and $0.006 \% \mathrm{H}_{2} \mathrm{O}_{2}$. The DAB reaction was terminated by three quick Tris buffer rinses. Sections were mounted on chrom-alum subbed slides, dried, dehydrated in graded ethanols, cleared in Hemo-De (Fisher Scientific, Houston, TX), and coverslipped with Permount (Fisher Scientific). As a negative control, adjacent sections were processed as described above with primary antibody omission. As an additional control, sections from P4 and P10 brains were incubated with PG-21 preabsorbed with either the immunizing peptide AR-21 (MEVQLGLGRVYPRPPSKTYRG; $10 \times$ molar excess; gift from Dr. G. Prins) or a distant unrelated peptide, AR-460 (10× molar excess; amino acids $460-472$ of the human AR; gift from Dr. G. Prins), and subsequent tissue processing as described above.

The hamster facial nucleus is a compact group of cells with well defined boundaries located ventrolaterally in the brainstem. Facial motoneurons are a homogenous population of large multipolar neurons, varying in size, which are morphologically distinct from surrounding glial cells. No other motoneuron or interneuron is present in the facial nucleus, except FMNs. Numerous studies have documented the reliable identification of FMNs by morphology in many different species via Niss staining, retrograde labeling, and immunohistochemistry (Papez, 1927; Huppenbauer et al., 2001; Atobe et al., 2004; Moran and Graeber, 2004). For AR-immunocytochemistry analysis, experimental slides (+PG-21) and negative control slides ( $-\mathrm{PG}-21)$ were paired together and qualitatively evaluated at the light microscopic level for the presence or absence of androgen receptor immunoreactivity (AR-IR) by an observer "blind" to the experimental conditions. AR-IR was determined by comparing the adjacent sections of the + PG-21 slide with the - PG-21 slide. Labeled FMNs were identified by the following morphological criteria: location, size, and shape. Because there are no interneurons or other motoneurons in the facial nucleus, all labeled cells meeting the correct criteria could only be FMNs. Therefore, sections containing FMNs were classified as follows: AR-IR not present in the cell, AR-IR present in the cytoplasm only, or AR-IR present in the cytoplasm plus the nucleus. Representative sections containing bilateral facial motor nuclei through the nuclear group were chosen from each animal from all time points for computerized camera lucida tracing using the Neurolucida Brain Mapping system (MicroBrightField, Cochester, VT).

Nerve injury paradigm and hormone administration. On P7 during mid-light cycle, gonadally intact male and female pups were removed from the nest cage and placed in a separate cage on a heating pad; a collodion-soaked cotton ball was then put in the nest in place of the absent pups. Pups were anesthetized by cryoanesthesia, and the right facial nerve was exposed and transected immediately distal to its exit from the stylomastoid foramen, with the left facial nucleus serving as intact control. To prevent reinnervation, an $\sim 2-3 \mathrm{~mm}$ distal section of nerve was removed. At the time of injury, separate litters of axotomized animals were implanted with a subcutaneous time-release pellet (Innovative Research of America, Sarasota, FL) containing the following: lowdose TP (0.25 mg daily), high-dose TP (0.48 mg daily), DHT (0.83 mg daily), sham (matrix only) TP/DHT pellet, $\mathrm{E}_{2}$ ( $0.042 \mathrm{mg}$ daily), or sham (matrix only) $\mathrm{E}_{2}$ pellet in the dorsum of the back. Separate litters of axotomy-only animals (no pellet) were included as an additional set of controls. After wound closure with collodion, the pups were revived on a heating pad and returned to the dam. All pups in a given litter received the same injury and hormone treatment to prevent hormone crosscontamination. Postaxotomy survival time points were 1 or 4 weeks. There was an $n=3-6$ per group, for a total of 106 animals.

To rule out any effects of TP on normal cell numbers, additional nonaxotomized, normal animals were included in the study. There were eight groups of nonaxotomized controls: no pellet, sham TP pellet, and low-TP or high-TP pellets implanted on P7, which were killed at P14 or P35. There was an $n=4$ per group, for a total of 32 nonaxotomized animals.

To determine whether potential neuroprotective effects of TP on axotomized developing hamster FMNs were permanent, six pups (three males and three females) were axotomized on P7 as described above and implanted with low-dose TP at the time of injury. After 1 week of continuous hormone exposure, TP implants were removed on P14, and the postaxotomy survival time point was extended $93 \mathrm{~d}$ to P100.

FMN cell-counting procedures. As described previously (Kujawa et al., 1989), signs of facial nerve axotomy include loss of eyeblink, complete loss of vibrissa movement, and abnormal vibrissa orientation with fibers flattened in a posterior direction against the head. At the appropriate time points, the animals were removed from the nest cage, sex verified by ano-genital distance measurement, checked for positive axotomy signs, 
weighed, deeply anesthetized with methyoxyflurane, and killed by decapitation. Postmortem dissection was performed to verify gender and presence of hormone implant. The brains were removed and rapidly frozen. Serial $25 \mu \mathrm{m}$ cryostat sections were collected throughout the caudalrostral extent of the facial motor nucleus, and the sections were fixed in $4 \%$ paraformaldehyde and stained with thionin.

A traditionally used counting method in neuronal regeneration research has been the Abercrombie counting method, in which a mathematical formula is used to convert object counts in a section into an estimate of object numbers (Hedreen, 1998). This method provides a relative percentage change per histological section, not a count of absolute neuronal numbers, when the injured and intact control nuclear groups are both at the same level in the brain. This method has been proven to be a reliable and reproducible method for obtaining relative percentage changes in neuronal survival and regeneration studies. Therefore, the Abercrombie counting method was used to determine the relative number of surviving FMNs after a facial nerve axotomy. As described previously, animal groups were coded by one investigator and subsequently analyzed under blind conditions by a second investigator who was unaware of the group divisions. The abducens nuclei and internal genu of the facial nerves were used to precisely match the location of the left (control) and right (transected) sides. Cell profile counts were performed on every $25 \mu \mathrm{m}$ section, and the percentage change between the left and right sides was calculated and compared between groups. Only surviving FMNs containing a clearly visible nucleus were counted (Serpe et al., 1999, 2000, 2003, 2005; Byram et al., 2003, 2004). The Abercrombie correction factor $(N=n \times T / T+D)$, where $N$ is the actual number of cells, $n$ is the number of nuclear profiles, $T$ is the section thickness ( 25 $\mu \mathrm{m})$, and $D$ is the average diameter of nuclei ( $12 \mu \mathrm{m}$ at $\mathrm{P} 14 ; 14 \mu \mathrm{m}$ at $\mathrm{P} 35$ and older) (Coggeshall, 1992), was used to compensate for double counting in adjacent sections. FMN nuclear diameters were obtained by sampling 10 random nuclei per animal and obtaining one average, combining males and females, per group. Additionally, the average number of FMNs per section in the left, unoperated nuclear group displaying a prominent nucleus and nucleolus (average nucleolar diameters, $3 \mu \mathrm{m}$ at P14 and $5 \mu \mathrm{m}$ at P35 and older) were sampled every fourth section through the extent of the facial nucleus to determine whether there were differences in neuronal numbers as a result of different hormone treatments. Statistical analysis was accomplished using a one-way ANOVA followed by the Student-Newman-Keuls post hoc test (Sokal and Rohlf, 1981).

\section{Results}

\section{ARs first appear in developing hamster FMNs by $\mathrm{P} 2$ in males} and by $\mathrm{P} 4$ in females

To determine when androgen receptors first appear in hamster FMNs, an AR immunocytochemistry time-course study using PG-21, an anti-AR antibody that has been well documented in the hamster (Wood et al., 1992; Wood and Newman, 1993, 1995, 1999; Romeo et al., 2000), was performed on brainstem tissue sections from males and females ranging in age from P0 to P10. The AR is a steroid receptor that resides in the cytoplasm in an unliganded state and, after ligand binding, translocates to the nucleus (Kumar and Thompson, 1999; Aranda and Pascual, 2001). For light microscopic analysis of AR-IR, a commonly used method of concentrating dispersed amounts of cytoplasmic AR into the nucleus is ligand injection shortly before the animals are killed (Zhou et al., 1994; Nunez et al., 2003). Therefore, all animals were injected with TP a minimum of 30 min before perfusion-fixation. At P10, FMNs from both male and female hamsters displayed AR-IR (Fig. 1 $a$; only data from males are shown). In control experiments in which the primary antibody was either omitted (Fig. $1 b$ ) or preabsorbed with the immunizing peptide AR-21 (Fig. 1c), AR-IR was abolished. As a final control, the primary antibody was preabsorbed with a nonimmuninizing peptide, AR-460, and in this case, AR-IR is not affected (Fig. 1d). As illustrated at high power in the light micrographs in Figure 2,
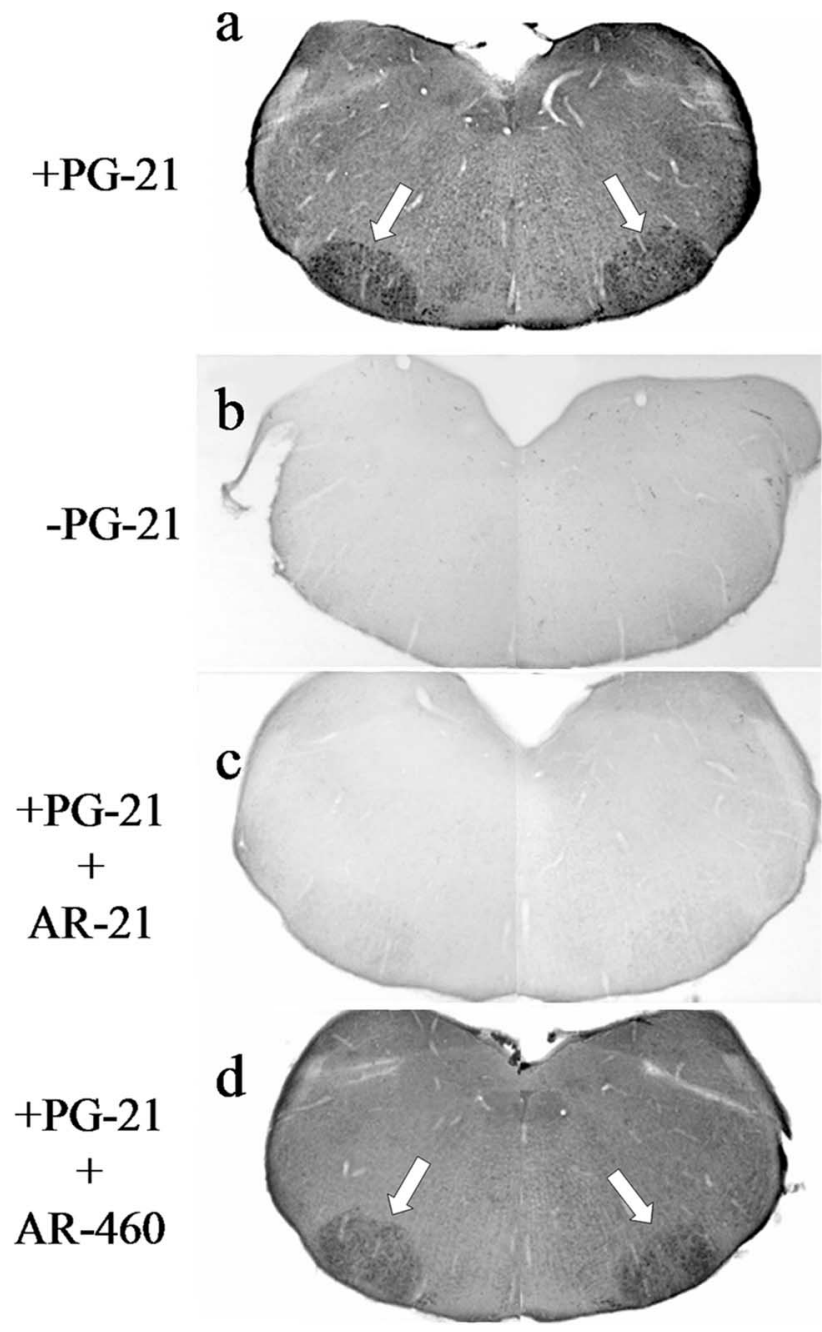

Figure 1. P10 hamster FMNs express AR. $\boldsymbol{a}$, A low-power (original magnification, 20X) composite photomicrograph of brainstem sections from P10 hamsters containing bilateral facial nuclei (white arrows) and processed for AR immunocytochemistry using the anti-AR antibody PG-21. Control experiments include omission of PG-21 primary antibody (b), preabsorption of PG-21 primary antibody with the immunizing peptide AR-21 (c), and preabsorption of $\mathrm{PG}-21$ primary antibody with an AR peptide that is distant and unrelated to immunizing peptide $(\boldsymbol{d})$.

when AR-IR was present in FMNs, it was observed either in the cytoplasm only (Fig. $2 a$ ) or in both the cytoplasm and nucleus (Fig. 2b). Both types of AR-IR were abolished with immunizing peptide preabsorption (Fig. $2 c, d$ ).

The developmental time course of AR expression in male hamster FMNs is illustrated in Figure 3. No AR-IR was observed at P0 (Fig. 3a). Cytoplasmic-only AR-IR was first observed at P2 (Fig. $3 b$ ), with cytoplasmic plus nuclear AR-IR first appearing at P4 (Fig. 3c) and continuing through P6 and P8 (Fig. 3d,e, respectively). All AR-IR, both cytoplasmic only and cytoplasmic plus nuclear, was abolished by omitting primary antibody (Fig. $3 f-j$ ).

The developmental time course of AR expression in female hamster FMNs is illustrated in Figure 4. No AR-IR was observed at $\mathrm{P} 0$ or P2 (Fig. 4a,b, respectively). Cytoplasmic-only AR-IR was first observed at P4 (Fig. 4c), with cytoplasmic plus nuclear AR-IR first appearing at P6 (Fig. 4d) and continuing through P8 (Figs. $4 e$ ). All AR-IR, both cytoplasmic only and cytoplasmic plus nuclear, was abolished by omitting primary antibody (Figs. $4 f-j$ ).

In Figure 5, Neurolucida computerized tracings of representative early postnatal hamster brainstem sections containing 


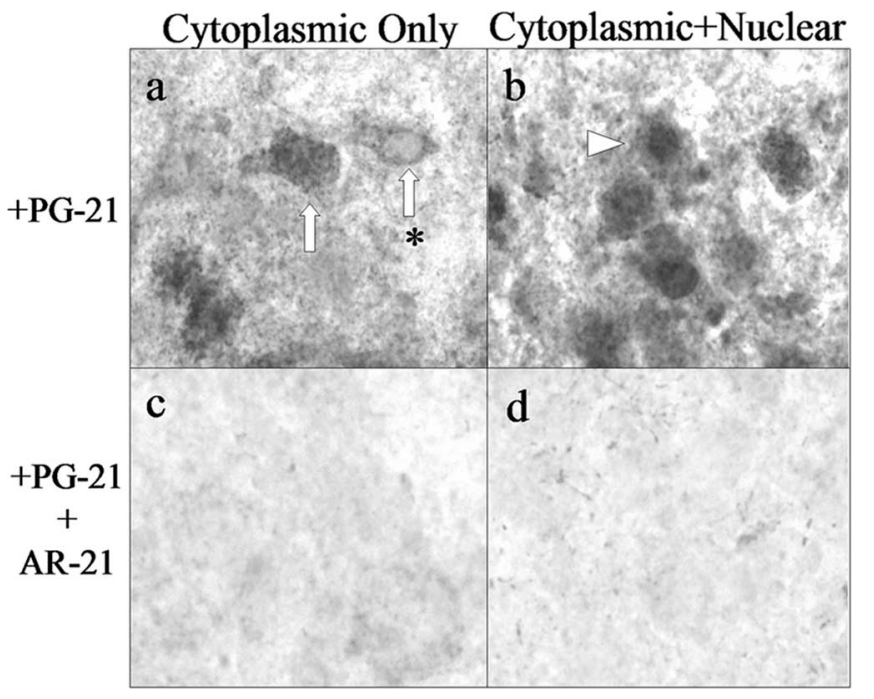

Figure 2. AR immunocytochemistry demonstrates that early cytoplasmic-only AR immunoreactivity is specific and not artifact. High-power photomicrographs (original magnification, $400 \times$ ) of FMNs from P4 hamsters processed for AR immunocytochemistry using the anti-AR antibody PG-21 are shown. Photomicrographs illustrate cytoplasmic FMN labeling ( $\boldsymbol{a}$, white arrows; asterisk denotes a nucleus that is devoid of label) as well as cytoplasmic plus nuclear labeling ( $\boldsymbol{b}$, arrowheads). Control experiments include preabsorption of $\mathrm{PG}-21$ primary antibody with the immunizing peptide AR-21 $(\boldsymbol{c}, \boldsymbol{d})$.

FMNs illustrate not only the topographical distribution of AR-IR within the facial nuclear groups, but also the first appearance of cytoplasmic-only AR-IR (red dots), the shift to cytoplasmic plus nuclear AR-IR (blue dots), and the temporal $2 \mathrm{~d}$ delay in the appearance of AR-IR in females compared with males. By P6, both male and female hamster FMNs expressed nuclear AR-IR after pretreatment with TP.

Testosterone is neuroprotective after facial nerve axotomy on P7 Previous work using the developing hamster facial nerve injury paradigm has established that significant cell death occurs as a result of injury during the first postnatal week (LaVelle and LaVelle, 1958, 1984; Jones and LaVelle, 1985, 1986, 1987; Clark et al., 1992, 1993). Based on that work and the results of the AR immunocytochemistry time-course study presented above, P7 was chosen as the best age to test the ability of gonadal steroids to rescue injured developing FMNs from axotomy-induced cell death. In non-hormone-treated male and female animals (no pellet or sham pellet), extensive FMN loss was observable at both 1 and 4 weeks after axotomy on P7. In hormone-treated animals, TP administered at the time of injury, with continuous exposure throughout the survival period, significantly reduced FMN cell loss (Figs. 6, 7, respectively; only data from males are shown).

As graphed in Figure 8, quantitative analysis corroborated the qualitative results described in the preceding paragraph. At 1 week after axotomy on P7, FMN survival was $57 \pm 1.3 \%$ in nonhormone-treated (no pellet) males and $56 \pm 2.9 \%$ in nonhormone-treated (no pellet) females (Fig. $8 a, b$, respectively). For pups that received a sham testosterone pellet at the time of axotomy on P7, FMN survival was $59 \pm 3.5 \%$ in males and $59 \pm$ $3.0 \%$ in females (Fig. $8 a, b$, respectively). For pups that received a TP pellet that released at a rate of $0.25 \mathrm{mg} / \mathrm{d}$, FMN survival was $84 \pm 1.7 \%$ in males and $83 \pm 1.9 \%$ in females (Fig. $8 a, b$, respectively). For pups that received a TP pellet that released at rate of $0.48 \mathrm{mg} / \mathrm{d}$, FMN survival was $83 \pm 1.1 \%$ in males and $82 \pm 1.1 \%$ in females (Fig. $8 a, b$, respectively).
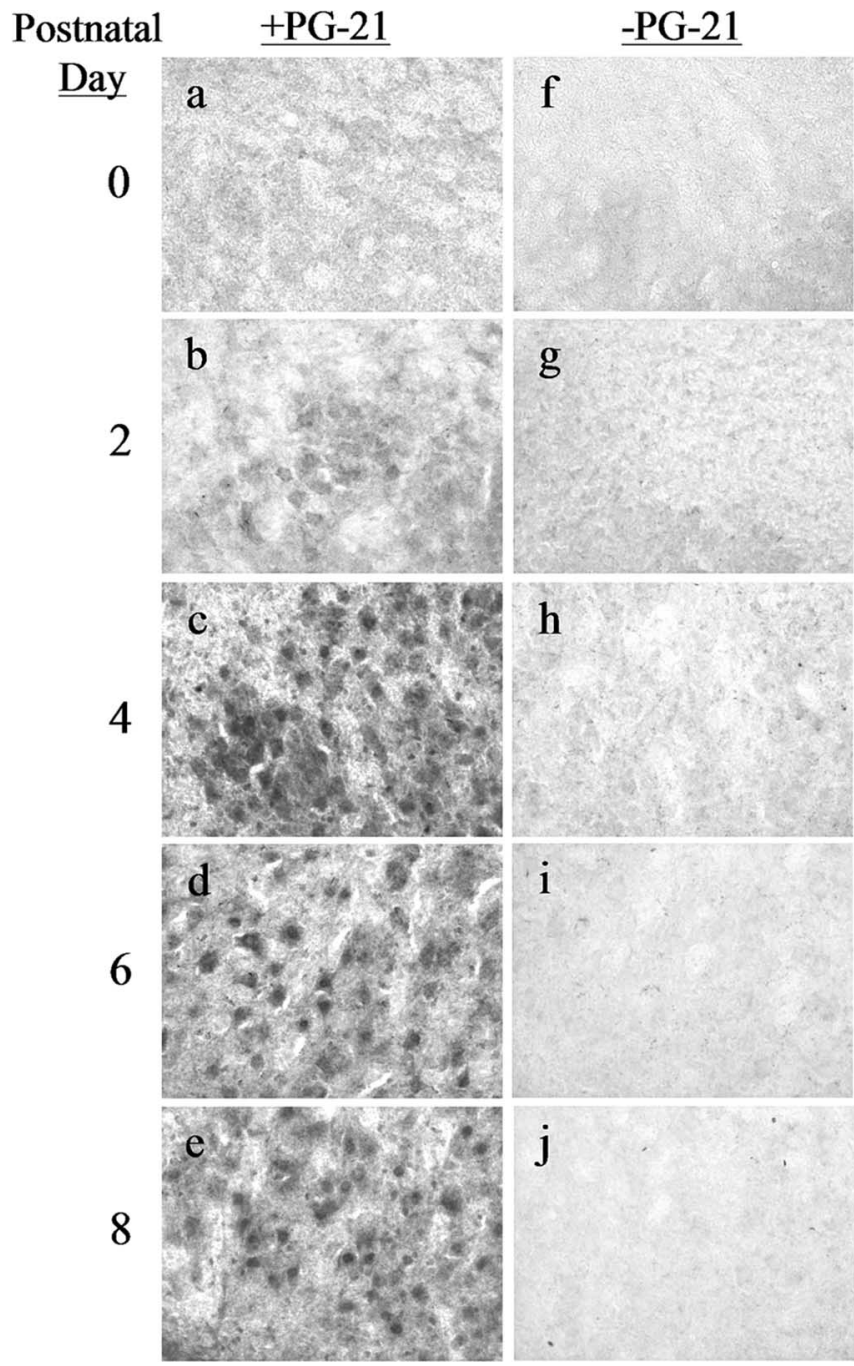

j

Figure 3. ARs first appear in developing hamster FMNs by $\mathrm{P} 2$ in males. High-power photomicrographs (original magnification, $200 \times)$ of developing male hamster FMNs at PO $(\boldsymbol{a}, \boldsymbol{f})$, P2 $(\boldsymbol{b}, \boldsymbol{g})$, P4 $(\boldsymbol{c}, \boldsymbol{h})$, P6 $(\boldsymbol{d}, \boldsymbol{i})$ and P8 $(\boldsymbol{e}, \boldsymbol{j})$ are shown. Left, Sections incubated with anti-AR antibody PG-21. Right, Adjacent sections processed without primary antibody.

Four weeks after axotomy on P7, FMN survival was $62 \pm 1.0 \%$ in non-hormone-treated (no pellet) males and $62 \pm 1.8 \%$ in non-hormone-treated (no pellet) females (Fig. $8 c, d$, respectively). For pups that received a sham pellet at the time of axotomy on P7, FMN survival was $59 \pm 1.8 \%$ in males and $61 \pm$ $4.3 \%$ in females (Fig. $8 c, d$, respectively). For pups that received a TP pellet that released at a rate of $0.25 \mathrm{mg} / \mathrm{d}$, FMN survival was $82 \pm 3.2 \%$ in males and $82 \pm 3.0 \%$ in females (Fig. $8 c$, $d$, respectively). For pups that received a TP pellet that released at rate of $0.48 \mathrm{mg} / \mathrm{d}, \mathrm{FMN}$ survival was $82 \pm 1.2 \%$ in males and $84 \pm 1.8 \%$ in females (Fig. $8 c, d$, respectively). Thus, within 1 week after axotomy, both low and high doses of TP, administered at the time of injury, significantly increased FMN survival to maximal levels in both male and female hamsters $(p<0.05)$. Moreover, levels of FMN survival at 1 and 4 weeks after axotomy were not statistically different, indicating that no additional cell death or neuroprotection by TP was occurring later than 1 week postoperative.

The neuroprotective effects of TP on FMN survival after facial nerve axotomy on $\mathrm{P} 7$ are both androgenic and estrogenic

Because TP can be converted to estrogen via aromatase, and given that aromatase levels are at their highest during development 


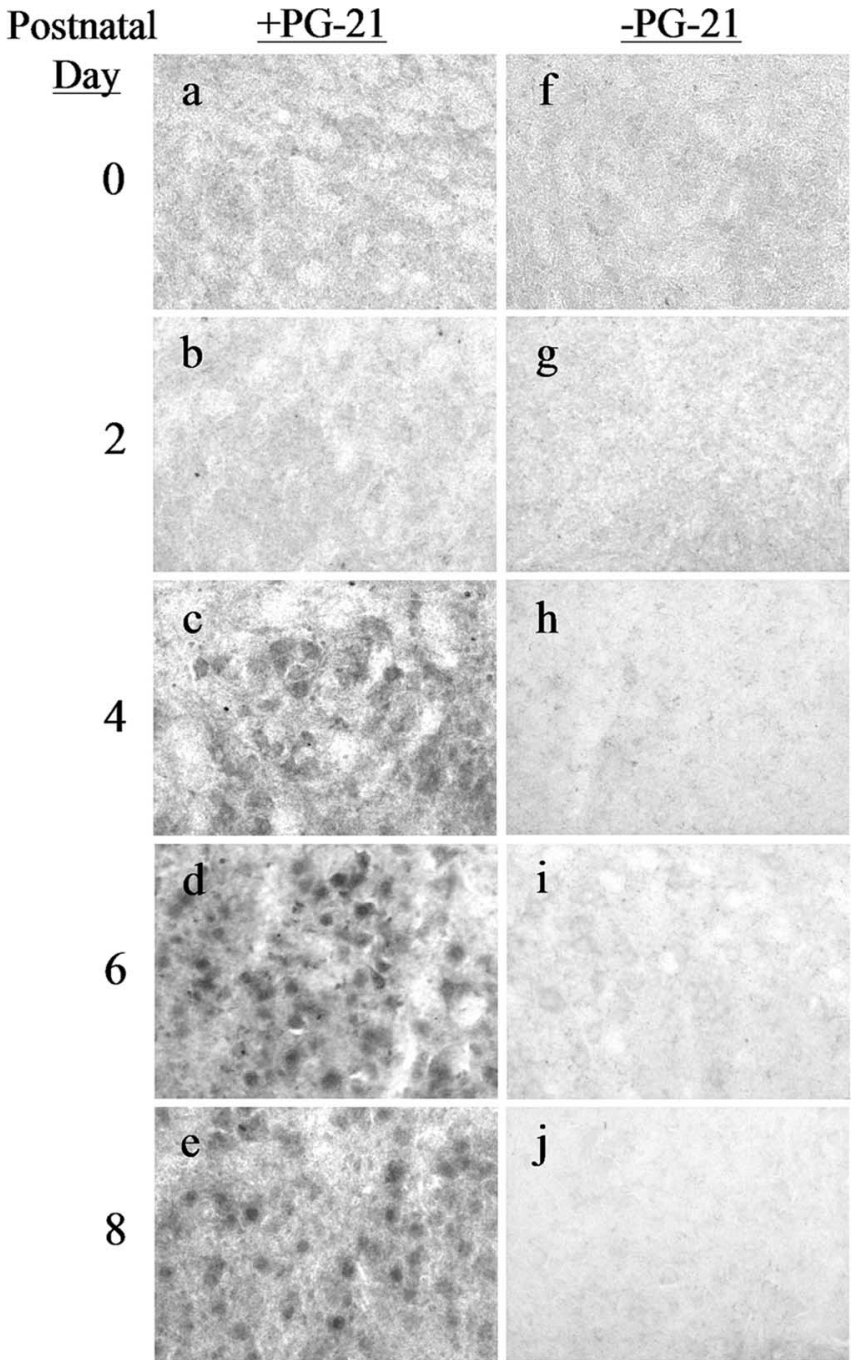

Figure 4. ARs first appear in developing hamster FMNs by $\mathrm{P} 4$ in females. High-power photomicrographs (original magnification, $200 \times$ ) of developing female hamster FMNs at PO $(\boldsymbol{a}, \boldsymbol{f})$, P2 $(\boldsymbol{b}, \boldsymbol{g})$, P4 $(\boldsymbol{c}, \boldsymbol{h})$, P6 $(\boldsymbol{d}, \boldsymbol{i})$, and P8 $(\boldsymbol{e}, \boldsymbol{j})$ are shown. Left, Sections incubated with anti-AR antibody PG-21. Right, Adjacent sections processed without primary antibody.

(Toran-Allerand, 1984; Stoffel-Wagner, 2001), the possibility that TP exerts its neuroprotective effects via conversion to estrogen was tested. Because the experiment with TP indicated that the amount of steroid rescue of injured FMNs from axotomyinduced cell death was equivalent at both 1 and 4 weeks after injury, only the 1 week postaxotomy survival time point was used for the remaining experiments. For pups that received an $\mathrm{E}_{2}$ pellet at the time of axotomy on P7, FMN survival was $84 \pm 4.8 \%$ in males (Fig. 9a) and $80 \pm 4.2 \%$ in females (Fig. 9b) at 1 week after axotomy, with both values significantly higher $(p<0.05)$ than the sham $\mathrm{E}_{2}$ pellet controls $(61 \pm 1.7$ and $58 \pm 6.0$; males and females, respectively). No differences in FMN survival were observed between the sham $\mathrm{E}_{2}$, sham testosterone pellet, or no pellet control groups (Fig. 8).

The nonaromatizable form of testosterone, dihydrotestosterone, was used to determine whether the effects of TP on FMN survival after axotomy at P7 were solely estrogenic or partially androgenic as well. For pups receiving a DHT pellet at the time of axotomy at P7, FMN survival was $84 \pm 1.2 \%$ in males (Fig. 9a) and $84 \pm 1.0 \%$ in females (Fig. $9 b$ ) at 1 week after axotomy, with both values significantly higher $(p<0.05)$ than the sham $\mathrm{E}_{2}$

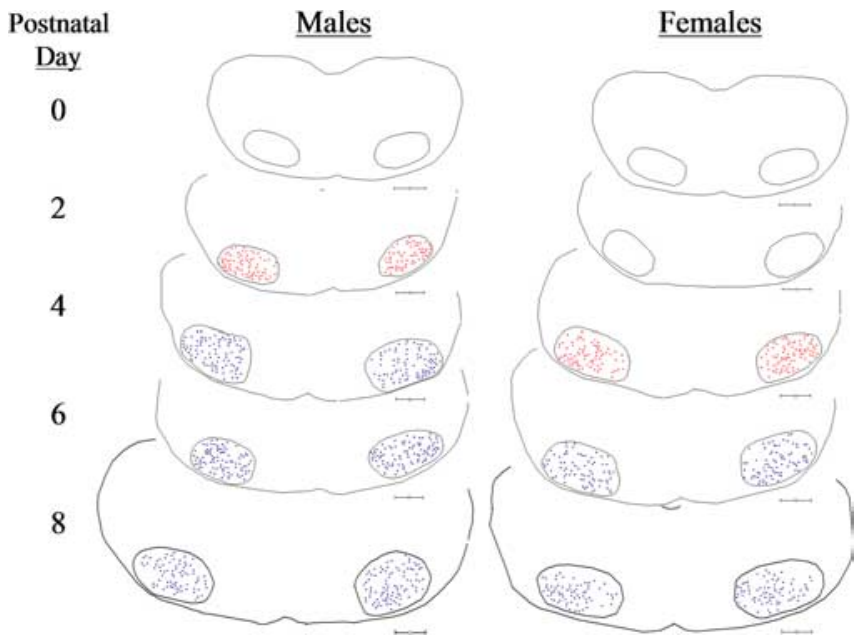

Figure 5. AR expression first occurs in male hamster FMNs by $\mathrm{P} 2$ and is delayed by $2 \mathrm{~d}$ in females. Neurolucida tracings of brainstem sections containing bilateral facial nuclei from an $A R$ immunocytochemistry developmental time-course study in P0, P2, P4, P6, and P8 male and female hamsters are shown. Red dots represent cytoplasmic-only FMN labeling. Blue dots represent cytoplasmic plus nuclear FMN labeling. Scale bars, $300 \mu \mathrm{m}$.

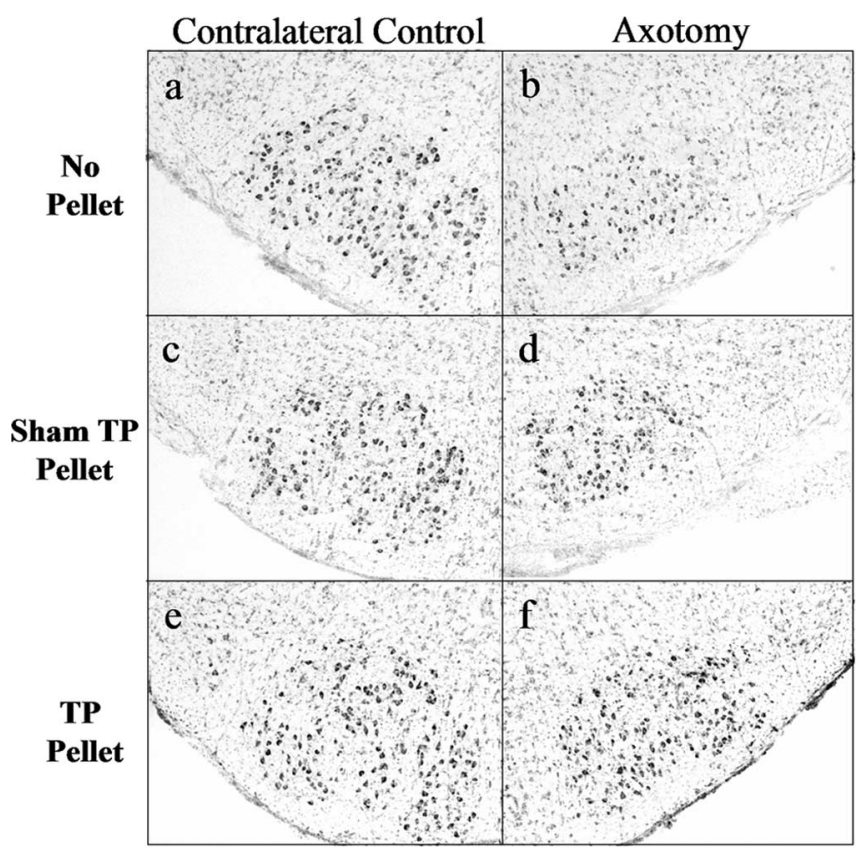

Figure 6. TP treatment rescues developing hamster FMNs from axotomy-induced cell death. Low-power (original magnification, $40 \times$ ) photomicrographs of thionin-stained sections containing contralateral control and axotomized facial nuclei 1 week postoperative from male hamsters injured on P7 are shown.

pellet controls $(61 \pm 1.7$ and $58 \pm 6.0$; males and females, respectively).

Finally, comparison of the data from all hormone treatment groups indicated that there were no differences between TP, DHT, or $\mathrm{E}_{2}$ administration on FMN survival in either males or females at 1 week after axotomy (compare Figs. 8, 9). Also, there were no differences in the average number of FMNs counted per section in the contralateral control (nonaxotomized) sides of any of the hormone treatment groups at either P14 or P35 (supplemental Table 1, available at www.jneurosci.org as supplemental material). Pup weight was unaffected by hormone treatment 


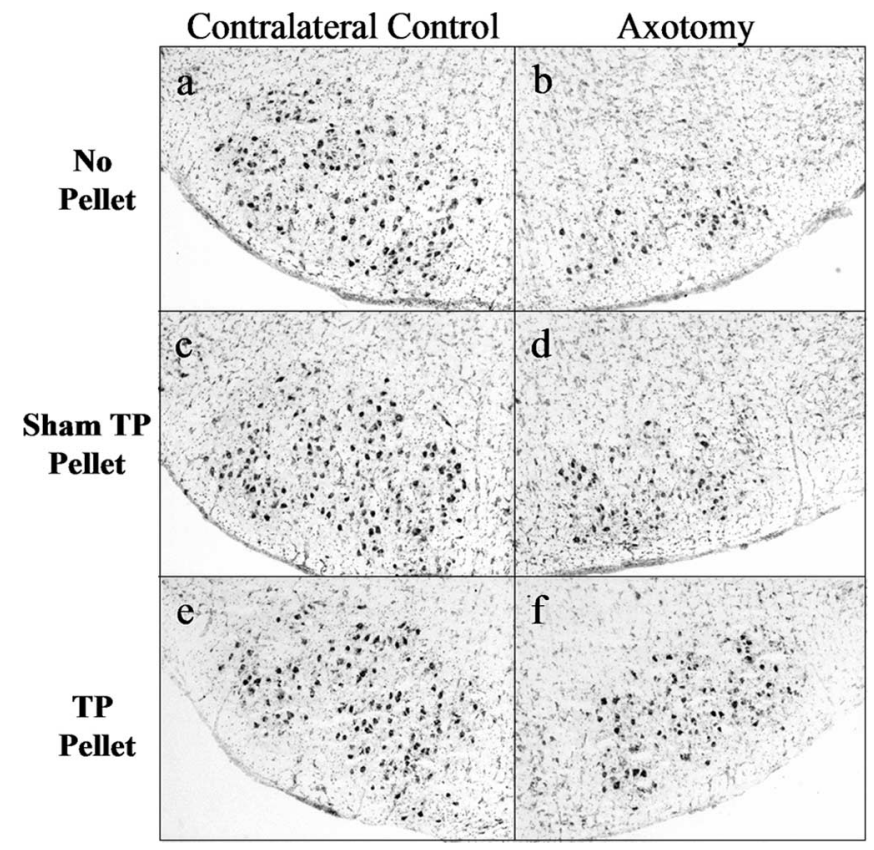

Figure 7. TP treatment rescues developing hamster FMNs from axotomy-induced cell death. Low-power (original magnification, $40 \times$ ) photomicrographs of thionin-stained sections containing contralateral control and axotomized facial nuclei 4 weeks postoperative from male hamsters injured on P7 are shown.

(supplemental Table 2, available at www.jneurosci.org as supplemental material).

\section{Hormone administration alone does not alter normal FMN numbers}

Additional, unoperated male and female hamsters were included in the study to verify that steroid treatment did not influence numbers of FMN, either by impacting programmed cell death or through neurogenesis. As illustrated in Figure 10 and documented in supplemental Table 3 (available at www.jneurosci.org as supplemental material), there were no differences in the average number of FMNs counted per section in the right or left facial nucleus of either P14 or P35 male or female hamsters, with or without TP administration.

\section{Nuclear diameter is not affected by hormone administration or axotomy}

When applying the Abercrombie correction factor, changes in cell volume induced by either steroid hormone treatment and/or axotomy can potentially introduce a source of bias in the counting procedure. Therefore, in the present study, only FMNs containing a clear nucleus were counted, in which the average nuclear diameter for each group was determined to apply the Abercrombie correction factor and used to monitor potential volume changes. It was found that the average nuclear diameters of transected FMNs $(\mathrm{P} 7,12.0 \pm 1.1$; P35, $14.0 \pm 1.5$ in the nonhormone-treated group) were not significantly different from those in the contralateral control FMNs (P7, $12.8 \pm 1.5$; P35, $14.2 \pm 1.1$ in the non-hormone-treated group); thus, left and right nuclear diameters at each age and for each treatment group were combined for formula use. Moreover, steroid hormone treatment not did affect the combined average FMN nuclear diameter when comparing the different steroid hormone treatment groups. The combined average FMN nuclear diameters for the different steroid hormone treatment groups in P14 animals were as follows: nonhormone treated, $12.4 \pm 1.3 \mu \mathrm{m}$; TP treated, $12.6 \pm 1.1 \mu \mathrm{m}$; DHT treated, $12.2 \pm 1.0 \mu \mathrm{m}$; and $\mathrm{E}_{2}$ treated $=$ $11.9 \pm 1.5 \mu \mathrm{m}$. The average FMN nuclear diameters for P35 animals were $14.2 \pm 1.6 \mu \mathrm{m}$ for non-hormone-treated and $14.1 \pm 1.4 \mu \mathrm{m}$ for TP-treated animals.

\section{The neuroprotective effects of TP on FMN survival after short-term hormone exposure are permanent}

To determine whether the neuroprotective effects exerted by TP were permanent, pups were axotomized on P7 and implanted with low-dose TP at the time of injury. One week after axotomy, TP implants were removed (P14), and animals survived for an additional $93 \mathrm{~d}$ (100 d postaxotomy). FMN survival levels were $81 \pm 1.5 \%$ in males and $80 \pm 1.1 \%$ in females, statistically comparable with survival levels $7 \mathrm{~d}$ after axotomy on $\mathrm{P} 7$ and indicative of permanent rescue.

\section{Discussion}

Over the past decade, we have established a neurotherapeutic role for gonadal steroids in neural injury and repair (Kujawa et al., 1989, 1991; Jones, 1993b). Adult hamster peripheral and central motoneurons respond with enhanced regenerative properties when steroids are exogenously administered, in supraphysiological levels, at the time of injury (Storer et al., 2002; Storer and Jones, 2003). After facial nerve injury in the adult hamster, both androgens and estrogens accelerate the rate of facial nerve regeneration (Tanzer and Jones, 1997). More recently, the concept of gonadal steroids as neuroprotective agents has emerged (GarciaSegura et al., 2001), with estrogens being the primary focus. With regard to axotomy-induced cell death and potential rescue by gonadal steroids, analysis of androgenic versus estrogenic effects in one system has, heretofore, not been accomplished and is important to determine. From the results of the present study, we have (1) identified early postnatal expression of androgen receptors in hamster facial motoneurons and (2) established that both androgens and estrogen have the capacity to rescue immature hamster FMNs from axotomy-induced cell death, with the rescue effects apparently permanent.

Because testosterone propionate has been shown to augment neuronal regeneration and functional recovery, through an ARmediated mechanism in an adult injury paradigm, the initial focus of this study was to examine whether TP impacts neuronal survival in a developmental injury paradigm. Because $100 \%$ of adult hamster FMNs survive facial nerve axotomy (LaVelle and LaVelle, 1984), this question could only be addressed in early postnatal animals, in which a significant amount of axotomyinduced cell death occurs. A postnatal developmental time course of AR expression was, therefore, undertaken to identify an appropriate time point for axotomy. We discovered that hamster FMNs of both sexes begin to express ARs earlier in development that had been previously documented for mammalian motoneurons. Male hamster FMNs express cytoplasmic AR immunoreactivity by $\mathrm{P} 2$ and nuclear AR-IR by P4, with female FMN AR-IR offset in both categories by $2 \mathrm{~d}$.

In the unbound state, ARs reside in the cytoplasm and, after ligand binding, the receptor-ligand dimer is translocated to the nucleus to act as a transcription factor (Kumar and Thompson, 1999; Aranda and Pascual, 2001). In accordance with protocols for AR distribution studies in brain, animals were pretreated with TP shortly before perfusion to translocate dispersed cytoplasmic ARs into the nucleus, to produce a readily detectable signal (Zhou et al., 1994; Nunez et al., 2003). Despite pretreatment with TP, however, only cytoplasmic AR-IR was found in FMNs of both 
males and females, $2 \mathrm{~d}$ before robust nuclear AR-IR was observed. To rule out the possibility that the observed early cytoplasmic-only AR-IR was experimental artifact, additional control experiments were performed. In control experiments, either omission of the primary antibody or incubation of the primary antibody with the immunizing peptide abolished cytoplasmic and nuclear AR-IR, whereas incubation of the primary antibody with a peptide unrelated to the immunizing peptide (but part of the AR) did not affect either type of AR-IR. These data suggest that the cytoplasmic-only AR-IR, which persists in the presence of ligand, reflects a functionally immature AR protein, with a $2 \mathrm{~d}$ maturation time span.

In the hamster, axotomy within the first postnatal week produces substantial cell death (LaVelle and LaVelle, 1984). Therefore, $\mathrm{P} 7$ was selected to examine potential gonadal steroid rescue of FMN from axotomy-induced cell death, because AR was present in both sexes at this age. The results indicated that TP is capable of reducing axotomy-induced cell death in both males and females and at first glance contradicts several studies in which testosterone was not found to be neuroprotective. For example, in the developing rat FMN injury paradigm, in which the injury time point preceded AR expression in the motoneuron cell body (Yu and Cao, 1992; Tao and Aldskogius, 1998), no neuroprotection by testosterone was observed and can be ascribed to the lack of functional AR within injured motoneurons. Likewise, Tao and Aldskogius (1998) examined the effects of testosterone administered intramuscularly on avulsion-induced adult hypoglossal motoneuron cell death and found no effect. It is hypothesized that androgen binding to its receptor in muscle stimulates neurotrophic factor production within the muscle, and in turn, these neurotrophic factors are retrogradely transported to the cell body. Because avulsion injury physically disconnects innervating motoneurons from their target muscle, the neurotrophic factors produced by testosterone in the muscle were unable to reach the injured cell bodies to produce any appreciable neuroprotective effect. Moreover, androgenic rescue of motoneurons from cell death after injury have been shown in both avian and Xenopus systems (Perez and Kelley, 1996; Gould et al., 1999), with AR implicated in the mechanism of action. And finally, testosterone-mediated neuroprotection was also demonstrated in a human primary neuron culture system (Hammond et al., 2001), in which AR antagonists eliminated neuroprotective effects.

Substantial evidence exists in the literature for estrogens as neuroprotective agents in the brain after injury (Behl, 2002a,b; Rau et al., 2003). Because TP can be metabolized to either estrogen or DHT, thereby potentially exerting either androgenic, estrogenic, or both types of effects on target cells, additional experiments were done to examine the effects of TP metabolites on FMN survival after axotomy on P7. Importantly, we have shown previously that both estrogen and DHT are capable of positively impacting on the regenerative properties of adult FMNs (Tanzer and Jones, 1997), even in the absence of estrogen receptors (Tanzer et al., 1999). The results of the present study indicate that the

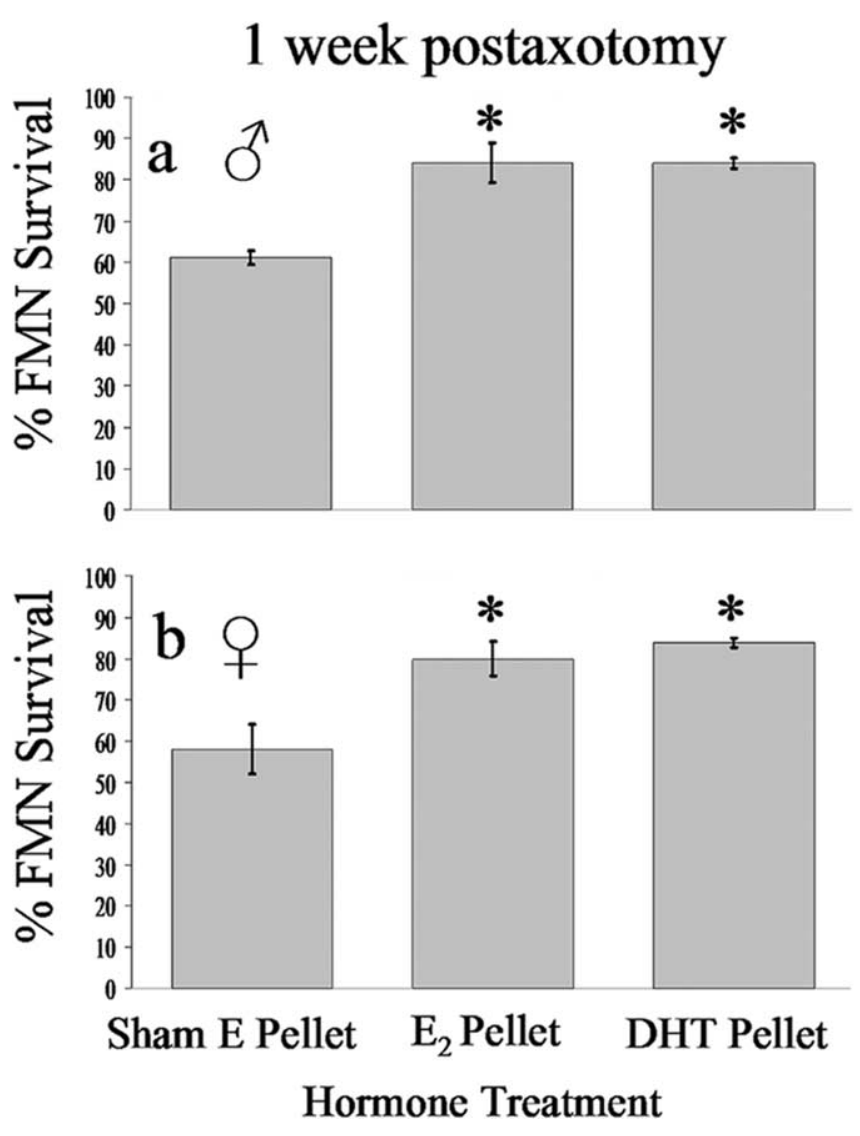

Figure 9. Estrogen and the nonaromatizable form of testosterone, DHT, equally reduce the amount of axotomy-induced cell death analogous to that of TP. Average percentage of FMN survival \pm SEM from the right (axotomized) side at 1 week postoperative from male ( $\boldsymbol{a}$ ) and female ( $\boldsymbol{b}$ ) hamsters axotomized on $\mathrm{P7}$, relative to the left (contralateral control) side are shown. *Significant differences at $p<0.01$. 


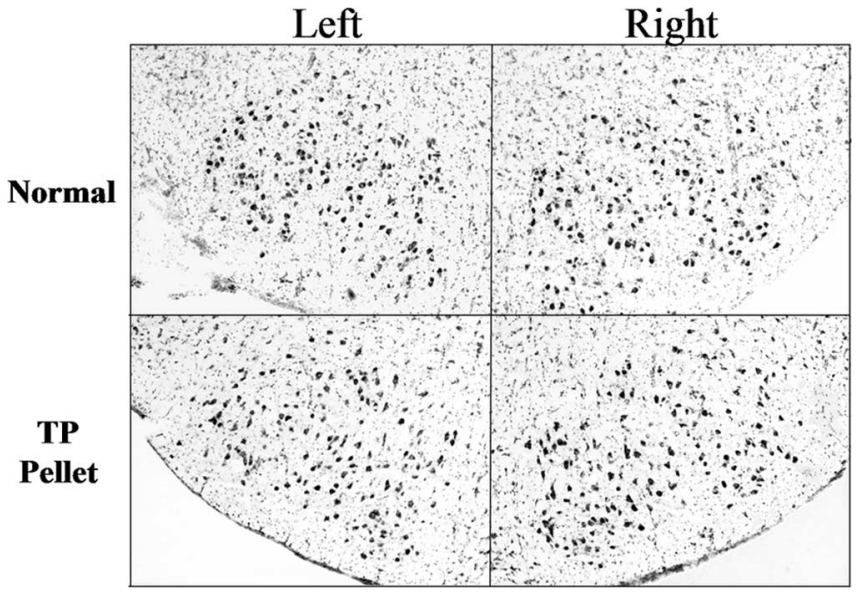

Figure 10. TP administration alone does not alter the number developing hamster FMNs. Low-power (original magnification, $40 \times$ ) photomicrographs of thionin-stained sections containing left and right facial nuclei from unoperated P35 male hamsters are shown. Normal, Unoperated controls; TP pellet, testosterone propionate pellet implanted on P7.

neuroprotective effects of TP can be ascribed to both estrogenic and androgenic actions, with mechanisms of action being receptor mediated for androgens and receptor independent estrogens. These data are in agreement with studies showing ovarian steroid rescue of developing rat FMNs from axotomy-induced cell death (Yu, 1989; MacLusky et al., 2003).

Given that both androgens and estrogens rescue developing FMNs from axotomy-induced cell death, several questions can be raised. How do steroids prevent neuronal cell death from occurring after injury? Are the mechanisms of action by the different steroids on the same cell type similar or distinct? What is the role of the specific receptors? Much of the available literature concerning gonadal steroids as neuroprotective agents involves estrogen and its actions through both receptor-independent and -dependent processes (Garcia-Segura et al., 2001; Behl, 2002b). Estrogenic effects on oxidative stress, neurotrophic factor expression, heat shock proteins, intracellular signaling cascades, and apoptosis have all been described (Azcoitia et al., 1999a,b; Dubal et al., 1999; Zhang et al., 2001, 2004; Cordey et al., 2003; Wang et al., 2003). Less is known about androgens as neuroprotective agents, with most of the literature suggesting that an ARdependent pathway is involved in the regulation of neurotrophic factor expression (Rasika et al., 1999; Xu et al., 2001), intracellular calcium levels (Perez and Kelley, 1997), and Bcl-2 expression (Park et al., 2002; Zup and Forger, 2002; Zup et al., 2003). Thus, either steroid could affect similar cellular pathways or gene expression in a given cell type, with androgens acting primarily through steroid receptor activation, and estrogens acting via classical receptor activation as well as novel nonreceptor pathways. Using steroid hormone autoradiography, we have not found estrogen receptor in adult hamster FMNs (Tanzer et al., 1999), although transient estrogen receptor expression has been found in the developing rat FMN (Hayashi, 1994; Orikasa et al., 1995). These studies predate the discovery of alternative forms of the estrogen receptor (Kuiper et al., 1996; Mosselman et al., 1996), necessitating a reexamination of ER expression in hamster FMNs.

In summary, the hamster FMN injury paradigm has proven to be a comprehensive model in which to study the neurotherapeutic actions of gonadal steroids. In the adult, the regenerative properties of injured FMNs are significantly enhanced by both androgenic and estrogenic steroids (Tanzer and Jones, 1997).
Although adult hamster FMN data demonstrate that the androgenic effects occur via a steroid receptor-mediated mechanism (Kujawa et al., 1995), the effects of estrogen on facial nerve regeneration remain to be determined. In the early postnatal animal, both androgens and estrogens rescue a subset of FMNs from axotomy-induced cell death. Again, the presence of ARs in immature FMNs implicates the steroid receptor in mediating the actions of androgens on FMN survival, whereas the mechanism by which estrogen rescues immature FMNs from axotomyinduced cell death remains to be determined. Historically, it has not been clear whether pathways leading to neuronal survival versus regeneration after axonal disconnection from target are linked. However, recent studies of motoneuron diseases in the mouse indicate that axonal defects in growth and maintenance, such as microtubule assembly, RNA processing, and axonal transport, have profound implications on motoneuron viability (Jablonka et al., 2004). The work that we have accomplished to date demonstrates that steroid regulation of neuronal injury and repair involves ribosomal RNA processing (Kinderman and Jones, 1993; Storer and Jones, 2003) and tubulin expression (Jones and Oblinger, 1994; Storer et al., 2002), which, together with the results of the present study, link the pathways for survival and axonal elongation after direct trauma. Future directions include investigation of ER- $\alpha$ and ER- $\beta$ expression in developing hamster FMNs using both immunocytochemistry and Western blot techniques and utilization of this model system for the investigation of cellular mechanisms related to motoneuron disease.

\section{References}

Aranda A, Pascual A (2001) Nuclear hormone receptors and gene expression. Physiol Rev 81:1269-1304.

Atobe Y, Nakano M, Kadota T, Hisajima T, Goris RC, Funakoshi K (2004) Medullary efferent and afferent neurons of the facial nerve of the pit viper Gloydius brevicaudus. J Comp Neurol 472:345-357.

Azcoitia I, Fernandez-Galaz C, Sierra A, Garcia-Segura LM (1999a) Gonadal hormones affect neuronal vulnerability to excitotoxin-induced degeneration. J Neurocytol 28:699-710.

Azcoitia I, Sierra A, Garcia-Segura LM (1999b) Neuroprotective effects of estradiol in the adult rat hippocampus: interaction with insulin-like growth factor-I signalling. J Neurosci Res 58:815-822.

Behl C (2002a) Oestrogen as a neuroprotective hormone. Nat Rev Neurosci 3:433-442.

Behl C (2002b) Estrogen can protect neurons: modes of action. J Steroid Biochem Mol Biol 83:195-197.

Byram SC, Serpe CJ, Pruett SB, Sanders VM, Jones KJ (2003) Natural killer cells do not mediate facial motoneuron survival after facial nerve transection. Brain Behav Immun 17:417-425.

Byram SC, Carson MJ, DeBoy CA, Serpe CJ, Sanders VM, Jones KJ (2004) $\mathrm{CD} 4$-positive $\mathrm{T}$ cell-mediated neuroprotection requires dual compartment antigen presentation. J Neurosci 24:4333-4339.

Clark P, Jones KJ, LaVelle A (1992) Alterations in nuclear envelope invaginations in axotomized fetal and early postnatal hamster facial motoneurons. Brain Res Dev Brain Res 68:1-8.

Clark P, Jones KJ, LaVelle A (1993) Metabolic changes in axotomized fetal and early postnatal hamster facial motoneurons: an autoradiographic study. Metab Brain Dis 8:115-124.

Coggeshall RE (1992) A consideration of neural counting methods. Trends Neurosci 15:9-13.

Cordey M, Gundimeda U, Gopalakrishna R, Pike CJ (2003) Estrogen activates protein kinase $\mathrm{C}$ in neurons: role in neuroprotection. J Neurochem 84:1340-1348.

Dubal DB, Shughrue PJ, Wilson ME, Merchenthaler I, Wise PM (1999) Estradiol modulates bcl-2 in cerebral ischemia: a potential role for estrogen receptors. J Neurosci 19:6385-6393.

Fargo KN, Sengelaub DR (2004) Exogenous testosterone prevents motoneuron atrophy induced by contralateral motoneuron depletion. J Neurobiol 60:348-359. 
Garcia-Segura LM, Azcoitia I, DonCarlos LL (2001) Neuroprotection by estradiol. Prog Neurobiol 63:29-60.

Gould TW, Burek MJ, Ishihara R, Lo AC, Prevette D, Oppenheim RW (1999) Androgens rescue avian embryonic lumbar spinal motoneurons from injury-induced but not naturally occurring cell death. J Neurobiol 41:585-595.

Hammond J, Le Q, Goodyer C, Gelfand M, Trifiro M, LeBlanc A (2001) Testosterone-mediated neuroprotection through the androgen receptor in human primary neurons. J Neurochem 77:1319-1326.

Hayashi S (1994) Immunocytochemical detection of estrogen receptor in the facial nucleus of the newborn rat by three antibodies with distinct epitopes. Horm Behav 28:530-536.

Hedreen JC (1998) What was wrong with the Abercrombie and empirical cell counting methods? A review. Anat Rec 250:373-380.

Huppenbauer CB, Tanzer L, Jones KJ (2001) Detection of retrogradely transported WGA-HRP in axotomized adult hamster facial motoneurons occurs after initiation of the axon reaction. J Neurocytol 30:907-916.

Jablonka S, Wiese S, Sendtner M (2004) Axonal defects in mouse models of motoneuron disease. J Neurobiol 58:272-286.

Jones KJ (1988) Steroid hormones and neurotrophism: relationship to nerve injury. Metab Brain Dis 3:1-18.

Jones KJ (1993a) Gonadal steroids as promoting factors in axonal regeneration. Brain Res Bull 30:491-498.

Jones KJ (1993b) Gonadal steroids and neuronal regeneration. A therapeutic role. Adv Neurol 59:227-240.

Jones KJ, LaVelle A (1985) Changes in nuclear envelope invaginations in axotomized immature and mature hamster facial motoneurons. Brain Res 353:241-249.

Jones KJ, LaVelle A (1986) Differential effects of axotomy on immature and mature hamster facial neurons: a time course study of initial nucleolar and nuclear changes. J Neurocytol 15:197-206.

Jones KJ, LaVelle A (1987) Differential effects of axotomy on immature and mature hamster facial neurons: a tritiated-uridine autoradiographic study. Metab Brain Dis 2:259-269.

Jones KJ, Oblinger MM (1994) Androgenic regulation of tubulin gene expression in axotomized hamster facial motoneurons. J Neurosci 14:3620-3627.

Jones KJ, Brown TJ, Damaser M (2001) Neuroprotective effects of gonadal steroids on regenerating peripheral motoneurons. Brain Res Brain Res Rev 37:372-382.

Kinderman NB, Jones KJ (1993) Testosterone enhancement of the nerve cell body response to injury: evidence using in situ hybridization and ribosomal DNA probes. J Neurosci 13:1523-1532.

Kuiper GG, Enmark E, Pelto-Huikko M, Nilsson S, Gustafsson JA (1996) Cloning of a novel receptor expressed in rat prostate and ovary. Proc Natl Acad Sci USA 93:5925-5930.

Kujawa KA, Jones KJ (1990) Testosterone-induced acceleration of recovery from facial paralysis in male hamsters: temporal requirements of hormone exposure. Physiol Behav 48:765-768.

Kujawa KA, Kinderman NB, Jones KJ (1989) Testosterone-induced acceleration of recovery from facial paralysis following crush axotomy of the facial nerve in male hamsters. Exp Neurol 105:80-85.

Kujawa KA, Emeric E, Jones KJ (1991) Testosterone differentially regulates the regenerative properties of injured hamster facial motoneurons. J Neurosci 11:3898-3906.

Kujawa KA, Tanzer L, Jones KJ (1995) Inhibition of the accelerative effects of testosterone on hamster facial nerve regeneration by the antiandrogen flutamide. Exp Neurol 133:138-143.

Kumar R, Thompson EB (1999) The structure of the nuclear hormone receptors. Steroids 64:310-319.

LaVelle A, LaVelle FW (1958) Neuronal swelling and chromatolysis as influenced by the state of cell development. Am J Anat 102:219-241.

LaVelle A, LaVelle F (1984) Neuron reaction to injury during development. In: Early brain damage: neurobiology, and behavior (Almli CR, ed), pp 3-16. New York: Academic.

MacLusky NJ, Chalmers-Redman R, Kay G, Ju W, Nethrapalli IS, Tatton WG (2003) Ovarian steroids reduce apoptosis induced by trophic insufficiency in nerve growth factor-differentiated PC12 cells and axotomized rat facial motoneurons. Neuroscience 118:741-754.

Moran LB, Graeber MB (2004) The facial nerve axotomy model. Brain Res Brain Res Rev 44:154-178.
Mosselman S, Polman J, Dijkema R (1996) ER beta: identification and characterization of a novel human estrogen receptor. FEBS Lett 392:49-53.

Nunez JL, Huppenbauer CB, McAbee MD, Juraska JM, DonCarlos LL (2003) Androgen receptor expression in the developing male and female rat visual and prefrontal cortex. J Neurobiol 56:293-302.

Orikasa C, Yokosuka M, Hayashi S (1995) Expression of estrogen receptor in the facial nucleus is suppressed by estradiol, but not by testosterone, indicating a lack of requirement for aromatization. Brain Res 693:112-117.

Papez JW (1927) Subdivisions of the facial nucleus. J Comp Neurol 43:159-191.

Park JJ, Zup SL, Verhovshek T, Sengelaub DR, Forger NG (2002) Castration reduces motoneuron soma size but not dendritic length in the spinal nucleus of the bulbocavernosus of wild-type and BCL-2 overexpressing mice. J Neurobiol 53:403-412.

Perez J, Kelley DB (1996) Trophic effects of androgen: receptor expression and the survival of laryngeal motor neurons after axotomy. J Neurosci 16:6625-6633.

Perez J, Kelley DB (1997) Androgen mitigates axotomy-induced decreases in calbindin expression in motor neurons. J Neurosci 17:7396-7403.

Prins GS, Birch L (1993) Immunocytochemical analysis of androgen receptor along the ducts of the separate rat prostate lobes after androgen withdrawal and replacement. Endocrinology 132:169-178.

Prins GS, Birch L, Greene GL (1991) Androgen receptor localization in different cell types of the adult rat prostate. Endocrinology 129:3187-3199.

Rasika S, Alvarez-Buylla A, Nottebohm F (1999) BDNF mediates the effects of testosterone on the survival of new neurons in an adult brain. Neuron 22:53-62.

Rau SW, Dubal DB, Bottner M, Gerhold LM, Wise PM (2003) Estradiol attenuates programmed cell death after stroke-like injury. J Neurosci 23:11420-11426.

Romeo RD, Diedrich SL, Sisk CL (2000) Effects of gonadal steroids during pubertal development on androgen and estrogen receptor-alpha immunoreactivity in the hypothalamus and amygdala. J Neurobiol 44:361-368.

Serpe CJ, Kohm AP, Huppenbauer CB, Sanders VM, Jones KJ (1999) Exacerbation of facial motoneuron loss after facial nerve transection in severe combined immunodeficient (scid) mice. J Neurosci 19:RC7(1-5).

Serpe CJ, Sanders VM, Jones KJ (2000) Kinetics of facial motoneuron loss following facial nerve transection in severe combined immunodeficient mice. J Neurosci Res 62:273-278.

Serpe CJ, Coers S, Sanders VM, Jones KJ (2003) CD4+ T, but not CD8 + or $\mathrm{B}$, lymphocytes mediate facial motoneuron survival after facial nerve transection. Brain Behav Immun 17:393-402.

Serpe CJ, Byram SC, Sanders VM, Jones KJ (2005) Brain-derived neurotrophic factor supports facial motoneuron survival after facial nerve transection in immunodeficient mice. Brain Behav Immun 19:173-180.

Sokal RR, Rohlf FJ (1981) Two-way ANOVA. In: Biometry, Ed 2, pp 299 337. San Francisco: Freeman.

Stoffel-Wagner B (2001) Neurosteroid metabolism in the human brain. Eur J Endocrinol 145:669-679.

Storer PD, Jones KJ (2003) Ribosomal RNA transcriptional activation and processing in hamster rubrospinal motoneurons: effects of axotomy and testosterone treatment. J Comp Neurol 458:326-333.

Storer PD, Houle JD, Oblinger M, Jones KJ (2002) Combination of gonadal steroid treatment and peripheral nerve grafting results in a peripheral motoneuron-like pattern of beta II-tubulin mRNA expression in axotomized hamster rubrospinal motoneurons. J Comp Neurol 449:364-373.

Tanzer L, Jones KJ (1997) Gonadal steroid regulation of hamster facial nerve regeneration: effects of dihydrotestosterone and estradiol. Exp Neurol 146:258-264.

Tanzer L, Jones KJ (2004) Neurotherapeutic action of testosterone on hamster facial nerve regeneration: temporal window of effects. Horm Behav 45:339-344.

Tanzer L, Sengelaub DR, Jones KJ (1999) Estrogen receptor expression in the facial nucleus of adult hamsters: does axotomy recapitulate development? J Neurobiol 39:438-446.

Tao R, Aldskogius H (1998) Influence of FK506, ayclosporin A, testosterone and nimodipine on motoneuron survival following axotomy. Restor Neurol Neurosci 12:239-246.

Toran-Allerand CD (1984) On the genesis of sexual differentiation of the general nervous system: morphogenetic consequences of steroidal exposure and possible role of alpha-fetoprotein. Prog Brain Res 61:63-98. 
Wang X, Simpkins JW, Dykens JA, Cammarata PR (2003) Oxidative damage to human lens epithelial cells in culture: estrogen protection of mitochondrial potential, ATP, and cell viability. Invest Ophthalmol Vis Sci 44:2067-2075.

Wise PM (2002) Estrogens and neuroprotection. Trends Endocrinol Metab 13:229-230.

Wood RI, Newman SW (1993) Intracellular partitioning of androgen receptor immunoreactivity in the brain of the male Syrian hamster: effects of castration and steroid replacement. J Neurobiol 24:925-938.

Wood RI, Newman SW (1995) Androgen and estrogen receptors coexist within individual neurons in the brain of the Syrian hamster. Neuroendocrinology 62:487-497.

Wood RI, Newman SW (1999) Androgen receptor immunoreactivity in the male and female Syrian hamster brain. J Neurobiol 39:359-370.

Wood RI, Brabec RK, Swann JM, Newman SW (1992) Androgen and estrogen concentrating neurons in chemosensory pathways of the male Syrian hamster brain. Brain Res 596:89-98.

Xu J, Gingras KM, Bengston L, Di Marco A, Forger NG (2001) Blockade of endogenous neurotrophic factors prevents the androgenic rescue of rat spinal motoneurons. J Neurosci 21:4366-4372.
Yu WH (1982) Effect of testosterone on the regeneration of the hypoglossal nerve in rats. Exp Neurol 77:129-141.

Yu WH (1989) Survival of motoneurons following axotomy is enhanced by lactation or by progesterone treatment. Brain Res 491:379-382.

Yu WH, Cao CG (1992) Testosterone fails to rescue motoneurons from axotomy-induced death in young rats. NeuroReport 3:1042-1044.

Zhang Y, Tounekti O, Akerman B, Goodyer CG, LeBlanc A (2001) 17- $\beta$ Estradiol induces an inhibitor of active caspases. J Neurosci 21:RC176(1-6).

Zhang Y, Champagne N, Beitel LK, Goodyer CG, Trifiro M, LeBlanc A (2004) Estrogen and androgen protection of human neurons against intracellular amyloid $\beta_{1-42}$ toxicity through heat shock protein 70 . J Neurosci 24:5315-5321.

Zhou L, Blaustein JD, De Vries GJ (1994) Distribution of androgen receptor immunoreactivity in vasopressin- and oxytocin-immunoreactive neurons in the male rat brain. Endocrinology 134:2622-2627.

Zup SL, Forger NG (2002) Testosterone regulates BCL-2 immunoreactivity in a sexually dimorphic motor pool of adult rats. Brain Res 950:312-316.

Zup SL, Carrier H, Waters EM, Tabor A, Bengston L, Rosen GJ, Simerly RB, Forger NG (2003) Overexpression of bcl-2 reduces sex differences in neuron number in the brain and spinal cord. J Neurosci 23:2357-2362. 